\title{
Isolation, Identification and Tyrosinase Inhibitory Activities of the Extractives from Allamanda cathartica
}

\author{
Kosei Yamauchi $^{1}$, Tohru Mitsunaga ${ }^{1}$, Irmanida Batubara ${ }^{2}$ \\ ${ }^{1}$ Faculty of Applied Biological Science, Gifu university, Gifu, Japan; ${ }^{2}$ Department of Chemistry, Faculty of Mathematics and Natural \\ Sciences, Biopharmaca Research Center, Bogor Agricultural University, Bogor, Indonesia. \\ Email: mitunaga@gifu-u.ac.jp,ime ime@ipb.ac.id
}

Received April 19 $9^{\text {th }}, 2011$; revised May $12^{\text {th }}, 2011$; accepted June $4^{\text {th }}, 2011$.

\begin{abstract}
Tyrosinase inhibitory activity of the extractives from A. cathartica was examined and their new bioactivity and potent active compounds were identified. Five compounds, glabridin, new lignan, kaempferol, naringenin, and allamandicin, were isolated by a series of chromatography, and identified by NMR and LC-MS. Among them, glabridin had the highest tyrosinase inhibitory activity $\left(\mathrm{IC}_{50}: 2.93 \mu \mathrm{M}\right)$ which is 15 times stronger than that of kojic acid used as positive control $\left(I C_{50}: 43.7 \mu M\right)$. Moreover the lignan was indentified as 1-[3-(4-allyl-2,6-dimethoxyphenoxy)-4-methoxyphenyl] propane-1,2, diol which was a novel lignan.
\end{abstract}

Keywords: Allamanda c athartica, Tyrosinase, Glabridin, Kaempferol, Naringenin, Allamandicin

\section{Introduction}

Allamanda cathartica is a plant cultivated in tropical area. It is used as decoction in various areas and is used in numerous ways. For instance, the extract is used as cathartic in South America and the stem extract is used as antihypertensive in Bangladesh [1-3]. However, the studies of components which have potent bioactivity in this plant are very few, and the mechanisms of the bioactivity have not been done sufficiently. Therefore, the aim of this study is to search active compounds from extract of this plant, and reveal the bioactive mechanism. We have been interesting to find the bioactive compounds from tropical plant extracts, and have identified some kinds of natural products relating to health and beauty so far. The present study examined tyrosinase inhibitory activity of the extractives from $A$. cathartica.

Melanin is a pigment which is biosynthesized from tyrosine by enzymatic oxidation of tyrosinase. Melanin is widely distributed in body surface, retina, nigra of brain, adrenal medullae, and so on. Moreover, it is thought to play an important role in skin cancer prevention by protection of cells from ultraviolent rays. While, it is said that melanin is a reason of sunburn and mottle. Therefore, compounds inhibiting melanin are expected to application of cosmetic as whitening agent. Melanin is biosyn- thesized in cells called melanocyte, and the starting material of biosynthesis is L-tyrosin. The key enzyme of melanin synthesis is tyrosinase which contains copper, and catalyzes two reactions in the melanin biosynthesis. In the cell, first key step of melanin biosynthesis is the oxidation of L-tyrosine to L-DOPA and second step is L-DOPA to L-DOPA quinine, which are catalyzed by tyrosinase. As the result, pheomelanin and eumelanin are produced. Pheomelanin is red-orange color and eumelanin is blackish brown.

Then, tyrosinase inhibitior makes melanin production diminishing, because the activity of this enzyme is rate-controlling step of melanin synthesis. We found that A. cathartica stem extract has tyrosinase inhibitory activity, and tried to search the center active compound. Some kind of tyrosinase inhibitors have been already found from plant extract [4-9]. We isolated 5 compounds (Figure 1) from extract of A.cathartica, and glabridin had the highest tyrosinase inhibitory activity among the compounds.

\section{Materials and Methods}

\subsection{Materials}

The sample was identified by Herbarium Bogoriense, Cibinong, Indonesia and deposited in Biopharmaca Research Center, Bogor Agricultural University no. 


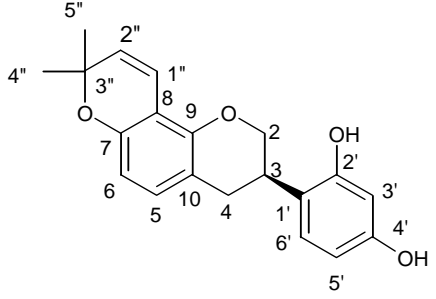

A: glabridin<smiles>C=CCc1cc(OC)c(Oc2cc(C(O)C(C)O)ccc2OC)c(OC)c1</smiles>

B: new lignan (1-(3-(4-allyl-2,6-dimethoxyphenoxy) -4-methoxyphenyl)propane-1,2, diol)<smiles>O=c1c(O)c(-c2ccc(O)cc2)oc2cc(O)cc(O)c12</smiles>

C: kaempferol<smiles>O=C1C[C@H](c2ccc(O)cc2)Oc2cc(O)cc(O)c21</smiles>

D: naringeni

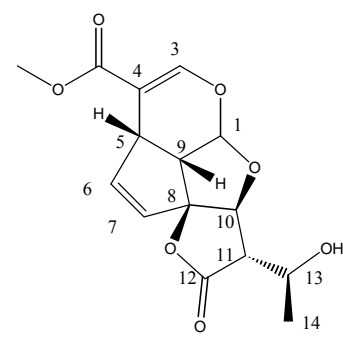

E: allamandicin

Figure 1. Structure of compound A-E.

1002002.

\subsection{Extraction and Fractionation of $A$. cathartica Stem Powder}

A. cathartica stem powder (385.4 g) was extracted with methanol. The methanol extract was fractionated with ethyl acetate. The ethyl acetate soluble fraction was separated with silica gel column chromatography $(69 \mathrm{~mm}$ $\varphi \times 510 \mathrm{~mm} \mathrm{~L}$ ). Eluted with $n$-hexane, EtOAc, $\mathrm{MeOH}$ to obtain Fr.1-Fr.8. The Fr.3 was separated with preparative HPLC[ODS-3 $(20 \mathrm{~mm} \varphi \times 250 \mathrm{~mm} \mathrm{~L})(\mathrm{MeOH} / 0.05 \%$ TFA aq.soln. $=10 / 90(0 \mathrm{~min}), 100 / 0(60 \mathrm{~min}), 100 / 0(80$ min)] to obtain Fr.3-1-Fr.3-4. Finally, compound A, B, C, D, and E were isolated from Fr.3-3, Fr.3-1, Fr.3-4, Fr.3-4, and Fr.3-4 respectively by preparative HPLC [ODS-3 (10 $\mathrm{mm} \varphi \times 250 \mathrm{~mm} \mathrm{~L})(\mathrm{MeOH} / 0.05 \%$ TFA aq.soln. $=10 / 90$ (0 min), 100/0 (60 min), 100/0 (80 min)] (Figure 2).

\subsection{Tyrosinase Activity Assay}

The tyrosinase activity method performed based on Batubara et al. (2010) [10]. Briefly, sample $70 \mu \mathrm{l}$ was put in 96-well plate. Tyrosinase $30 \mu \mathrm{l}(333 \mathrm{unit} / \mathrm{ml}$ in phosphate buffer $50 \mathrm{mM} \mathrm{pH} \mathrm{6.5)} \mathrm{and} 110 \mu \mathrm{l}$ of substrates (L-tyrosine $2 \mathrm{mM}$ or L-DOPA $12 \mathrm{mM}$ ) were added. After incubation at $37^{\circ} \mathrm{C}$ for $30 \mathrm{~min}$, the absorbance at $510 \mathrm{~nm}$ was determined using a micro plate reader. Moreover $\mathrm{IC}_{50}$ value (concentration of inhibitor showing 50\% inhibition) was calculated.

\subsection{Identification of Compounds}

Compound A-E were identified by ${ }^{1} \mathrm{H}-\mathrm{NMR},{ }^{13} \mathrm{C}-\mathrm{NMR}$, ${ }^{1} \mathrm{H}-{ }^{1} \mathrm{H}-\mathrm{COSY}, \mathrm{HMQC}, \mathrm{HMBC}$, and LC-MS. Aceton-d6 was used as the solvent for all compounds. These NMR measurements were performed by using JEOL EC600NMR.LC-MS measurements (Waters Waters ${ }^{\circledR}$ Xevo $^{\mathrm{TM}}$ QTof MS) was performed using column $\mathrm{C}_{18}(2.1 \times 100$ $\mathrm{mm})$ with $\mathrm{MeOH} /$ water $=60 / 40(0 \mathrm{~min}), 100 / 0(10 \mathrm{~min})$, $100 / 0$ (13 $\mathrm{min})$ as eluent.

The NMR data of compounds isolated from A. cathartica stem is shown in Table 1. LC-MS: $\mathrm{ES}^{-}$data of Compoun A, B, C, D, and E were m/z: 323 (M-1), 373, 285, 271, 307 respectively.

\section{Results and Discussion}

\subsection{Compounds Identification}

Allamanda cathartica contains hydrocarbons(long chain esters), e.g. 1-triacontanol, 1-dotriacontanol, docosanoic-, tetracosanoic- and hexacosanoic acid in the root; $\beta$-sitosterol and triterpenes e.g. ursolic acid and $\beta$-amyrin in the leaves or stem, and lupeol in the roots [1-3]. Other components isolated from the roots include series of iridoid lactones: allamadin, allamandicin, plumericin, isoplumericin, plumeieride and fluvoplumierin [11,12].

Compound A concluded as glabridin, while compound $\mathrm{C}$, D and E was kaempferol, naringenin, and allamandicin respectively. Interestingly, Kaempferol have 


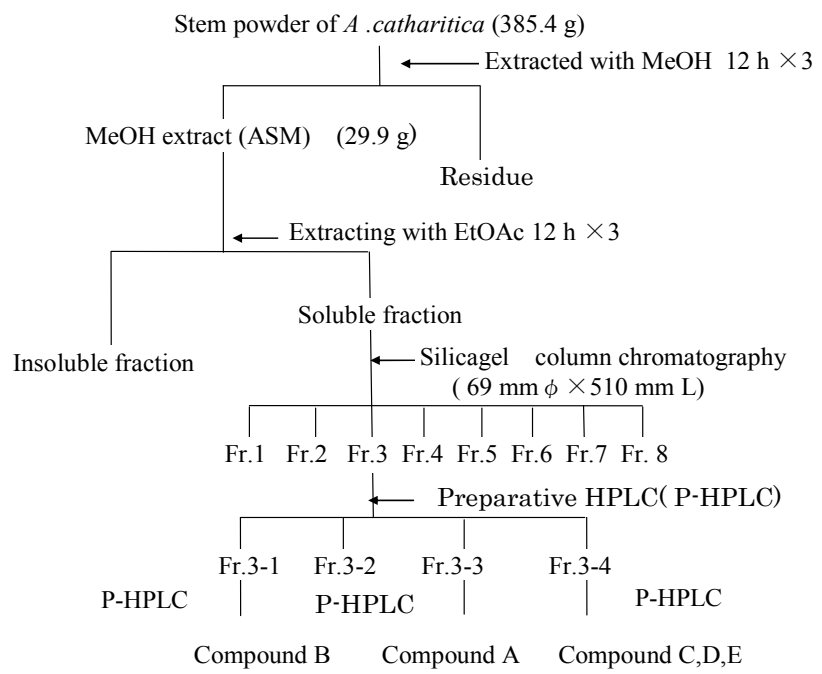

Figure 2. Isolation scheme of the compounds from $A$. catharitica stem powder.

been found in petals of this plant, and allamandicin have been found in roots[4]. However, it was revealed that the two compounds are also contained in stem. Moreover, glabridin and naringenin are found the first time in this plant.

NMR spectrum of glabridin was also searched, and tried to compare to data of compound A and glabridin. The NMR spectrum data from glabridin was similar to that of compound A. Equally, compound C, D, E were identified as keampferol, naringenin, allmandicin respectively [13-15].

Compound B was found to be a novel compound. According to NMR data for compound B, 5.11 and $5.07 \mathrm{ppm}$ protons were geminal and alkene protons because of chemical shift and HMQC data. The two protons of 6.55 ppm peeks were equivalen in aromatic ring protons, because it appeared as singlet proton. The three protons of $6.72,6.94,6.68 \mathrm{ppm}$ were also the aromatic protons indicating ortho-metha, ortho, and metha coupling. According to the HMBC spectrum of compound B (Figure 3), long-range correlations were observed between $\mathrm{H}-1$ and $\mathrm{C}-2, \mathrm{H}-2$ and $\mathrm{C}-1, \mathrm{C}-3, \mathrm{C}-4, \mathrm{H}-3$ and $\mathrm{C}-1, \mathrm{C}-2, \mathrm{C}-4$, $\mathrm{H}-5$ and $\mathrm{C}-3, \mathrm{C}-4, \mathrm{C}-6,6-\mathrm{OMe}$ and $\mathrm{C}-6,8-\mathrm{OMe}$ and $\mathrm{C}-8$, $\mathrm{H}-9$ and $\mathrm{C}-8, \mathrm{C}-4, \mathrm{C}-3, \mathrm{H}_{3}-1$ ' and $\mathrm{C}-2$ ', $\mathrm{C}-3$ ', $\mathrm{H}-2$ ' and C-3', H-3' and C-4', C-9', H-5' and C-3', C-4', C-6', C-7, 7'-OMe and C-7', H-8' and C-7', C-9' and between H-9' and C-8', C-3', C-4'. These NMR and MS data showed us the compound B is lignan 1-[3-(4-allyl-2, 6-dimetoxyphenoxy)-4-methoxyphenyl]propane-1,2,diol shown Figure 1.

\subsection{Tyrosinase Inhibitory Activity}

Allamanda crude extract and the fractions were analyzed for their activity against tyrosinase. The $\mathrm{IC}_{50}$ values of $\mathrm{MeOH}$ extract and fractions are shown in Table 2. Kojic acid is used as a positive control, because kojic acid is included in whitening agent of cosmetic products. Table 1 shows that $\mathrm{IC}_{50}$ value of $\mathrm{MeOH}$ extract is $98.4 \mu \mathrm{g} / \mathrm{ml}$, and that of Fr.3 is $8.35 \mu \mathrm{g} / \mathrm{ml}$. Thus, tyrosinase inhibition is becoming strong with following fractionation. Among to Fr.3-1 till Fr.3-4, Fr.3-3 had the strongest activity $\left(\mathrm{IC}_{50}\right.$ $0.589 \mu \mathrm{g} / \mathrm{ml}$ ).

From Fr.3-3, glabridin was isolated. Moreover, from Fr.3-1, lignan was isolated and from Fr.3-4, naringenin, kaempferol, and allamandicin were isolated. Their tyrosinase inhibitory activity are shown in Table 3. According to Table 3, only glabridin has potent activity. The tyrosinase inhibitory activity of glabridin is shown in Figure $\mathbf{4}$ for L-tyrosine as substrate and Figure $\mathbf{5}$ for L-DOPA as substrate. According to Figure 4, glabridin had about $93 \%$ of tyrosinase inhibition at concentration $19.3 \mu \mathrm{M}$ for reaction with L-tyrosine as substrate. While, Kojic acid had only about $28 \%$ inhibition at $54.9 \mu \mathrm{M}$ concentration. $\mathrm{IC}_{50}$ value of glabridin was $2.93 \mu \mathrm{M}$, and this value was lower than that of Kojic acid value $(43.7 \mu \mathrm{M})$.

Moreover, in Figure 5 (tyrosinase inhibitory activity using DOPA as the substrate), $\mathrm{IC}_{50}$ value of glabridin was $25.5 \mu \mathrm{M}$, and this value was lower than that of Kojic

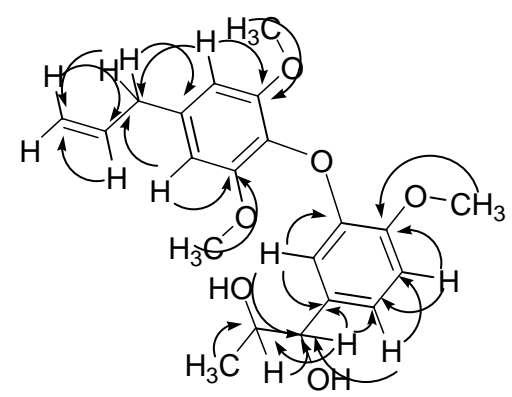

Figure 3. Key HMBC correlations of compound B. 
Table 1. ${ }^{1} \mathrm{H}$-NMR and ${ }^{13} \mathrm{C}-\mathrm{NMR}$ data of compound A-E.

\begin{tabular}{|c|c|c|c|c|c|c|c|}
\hline Position & Compound $\mathrm{A} \delta_{\mathrm{H}}$ & $\mathrm{J}(\mathrm{Hz})$ & $\delta_{\mathrm{C}}$ & Position & compound B $\delta_{\mathrm{H}}$ & $\mathrm{J}(\mathrm{Hz})$ & $\delta_{\mathrm{C}}$ \\
\hline \multirow[t]{2}{*}{2} & $4.31 \mathrm{~m}$ & & 70.1 & 1 & $5.11 \mathrm{dd}$ & $17.2,2.10$ & 115.1 \\
\hline & $3.97 \mathrm{t}$ & 10.3 & & & $5.01 \mathrm{dd}$ & $10.3,2.04$ & \\
\hline 3 & $3.47 \mathrm{~m}$ & & 31.7 & 2 & $5.97 \mathrm{~m}$ & & 137.7 \\
\hline \multirow[t]{2}{*}{4} & $2.95 \mathrm{dd}$ & $15.8,10.9$ & 30.4 & 3 & $3.34 \mathrm{~d}$ & 6.90 & 40.2 \\
\hline & $2.77 \mathrm{ddd}$ & $15.7,5.7,1.8$ & & 4 & & & 137.7 \\
\hline 5 & $6.81 \mathrm{~d}$ & 8.05 & 129.3 & 5 & \multirow[t]{4}{*}{$6.55 \mathrm{~s}$} & & 105.8 \\
\hline 6 & \multirow{7}{*}{$6.25 \mathrm{~d}$} & \multirow{7}{*}{8.55} & 108.4 & 6 & & & 153.7 \\
\hline 7 & & & 152.0 & 7 & & & 136.0 \\
\hline 8 & & & 109.6 & 8 & & & 153.7 \\
\hline 9 & & & 149.8 & 9 & $6.55 \mathrm{~s}$ & & 105.8 \\
\hline 10 & & & 114.8 & $\mathrm{OMe}$ & $3.83 \mathrm{~s}(6 \mathrm{H})$ & & 55.7 \\
\hline 1 , & & & 118.4 & 1 ' & $1.00 \mathrm{~d}$ & 6.18 & 12.6 \\
\hline 2 , & & & 156.1 & $2^{\prime}$ & $4.29 \mathrm{~m}$ & & 82.1 \\
\hline 3 , & \multirow[t]{2}{*}{$6.45 \mathrm{~d}$} & \multirow[t]{2}{*}{2.3} & 102.8 & $3^{\prime}$ & \multirow[t]{2}{*}{$4.70 \mathrm{~s}$} & & 73.0 \\
\hline 4 , & & & 157.4 & 4 ' & & \multirow{4}{*}{8.22} & 145.4 \\
\hline 5 , & $6.31 \mathrm{dd}$ & $8.3,1.75$ & 106.7 & 5 , & \multirow{3}{*}{$6.72 \mathrm{~d}$} & & 114.5 \\
\hline 6 , & $6.93 \mathrm{~d}$ & 15.5 & 128.7 & 6 ' & & & 133.4 \\
\hline $1 "$ & $6.68 \mathrm{~d}$ & 10.2 & 116.9 & 7 , & & & 147.3 \\
\hline $2 "$ & \multirow[t]{2}{*}{$5.57 \mathrm{~d}$} & \multirow{4}{*}{10.3} & 127.8 & 8, & $6.94 \mathrm{~d}$ & \multirow{4}{*}{$\begin{array}{c}1.38 \\
8.22,1.38\end{array}$} & 109.7 \\
\hline $3 "$ & & & 75.1 & 9 , & $6.68 \mathrm{dd}$ & & \multirow{3}{*}{$\begin{array}{r}118.6 \\
55.4\end{array}$} \\
\hline $4 "$ & $1.33 \mathrm{~s}$ & & 27.0 & $\mathrm{OMe}$ & $3.78 \mathrm{~s}(3 \mathrm{H})$ & & \\
\hline $5 "$ & $1.35 \mathrm{~s}$ & & 27.1 & & & & \\
\hline Position & Compound $\mathrm{C} \delta_{\mathrm{H}}$ & $\mathrm{J}(\mathrm{Hz})$ & $\delta_{\mathrm{C}}$ & Position & Compound $\mathrm{D} \delta_{\mathrm{H}}$ & $\mathrm{J}(\mathrm{Hz})$ & $\delta_{\mathrm{C}}$ \\
\hline 2 & & & 146.2 & 2 & $5.42 \mathrm{dd}$ & $2.76,13.1$ & 79.1 \\
\hline 3 & & & 135.8 & 3 & $2.70 \mathrm{dd}$ & $2.5,17.1$ & 42.7 \\
\hline & & & & & $3.20 \mathrm{~m}$ & & \\
\hline 4 & & & 175.8 & 4 & & & 196.4 \\
\hline 5 & & & 161.5 & 5 & & & 164.2 \\
\hline 6 & $6.23 \mathrm{~s}$ & & 98.4 & 6 & $5.93 \mathrm{~d}$ & 2.04 & 96.0 \\
\hline 7 & & & 164.2 & 7 & & & 166.6 \\
\hline 8 & $6.50 \mathrm{~s}$ & & 93.7 & 8 & $5.94 \mathrm{~s}$ & & 95.0 \\
\hline 9 & & & 157.0 & 9 & & & 163.6 \\
\hline 10 & & & 103.3 & 10 & & & 102.3 \\
\hline 1 , & & & 122.5 & 1 , & & & 129.9 \\
\hline 2 , & $8.11 \mathrm{~d}$ & 8.28 & 123.0 & 2 ' & $7.36 \mathrm{~d}$ & 8.28 & 128.2 \\
\hline 3 , & $6.98 \mathrm{~d}$ & 8.22 & 115.5 & 3 , & $6.87 \mathrm{~d}$ & 8.28 & 115.3 \\
\hline 4, & & & 159.4 & 4 , & & & 157.9 \\
\hline 5 , & $6.98 \mathrm{~d}$ & 8.22 & 115.5 & 5, & $6.87 \mathrm{~d}$ & 8.28 & 115.3 \\
\hline 6 , & $8.11 \mathrm{~d}$ & 8.28 & 123.0 & 6 ' & $7.36 \mathrm{~d}$ & 8.28 & 128.2 \\
\hline
\end{tabular}

\begin{tabular}{cccc}
\hline Position & Compound $\mathrm{E} \delta_{\mathrm{H}}$ & $\mathrm{J}(\mathrm{Hz})$ & $\delta_{\mathrm{C}}$ \\
\hline 1 & $5.67 \mathrm{~d}$ & 6.18 & 102.0 \\
3 & $7.40 \mathrm{~s}$ & & 152.6 \\
4 & $3.92 \mathrm{~m}$ & & 109.2 \\
5 & $5.92 \mathrm{dd}$ & $2.04,5,46$ & 38.2 \\
6 & $5.79 \mathrm{dd}$ & $2.10,5.52$ & 140.0 \\
7 & & & 127.9 \\
8 & $3.46 \mathrm{dd}$ & $6.18,9.60$ & 106.5 \\
9 & $4.70 \mathrm{~s}$ & & 53.6 \\
10 & $2.70 \mathrm{~d}$ & & 83.6 \\
11 & & & 55.2 \\
12 & $4.33 \mathrm{~m}$ & 6.18 & 175.9 \\
13 & $1.32 \mathrm{~d}$ & & 66.0 \\
14 & $3.69 \mathrm{~s}(3 \mathrm{H})$ & & 21.5 \\
$\mathrm{CO}$ & & & 166.4 \\
$\mathrm{OMe}$ & & & 50.9 \\
\hline
\end{tabular}


Table 2. Tyrosinase inhibitory activity of extract and fractions from A. cathartica stem.

\begin{tabular}{|c|c|c|c|c|c|c|c|c|c|c|}
\hline & $\begin{array}{c}\text { Kojic } \\
\text { acid }\end{array}$ & $\begin{array}{l}\mathrm{MeOH} \\
\text { extract }\end{array}$ & Fr.1 & Fr.2 & Fr.3 & Fr.4 & Fr. 5 & Fr.6 & Fr.7 & Fr. 8 \\
\hline \multirow[t]{2}{*}{$\mathrm{IC}_{50}(\mu \mathrm{g} / \mathrm{ml})$} & 6.18 & 98.4 & $100<$ & 95.7 & 8.35 & 89.1 & $100<$ & $100<$ & $100<$ & $100<$ \\
\hline & Fr.3-1 & Fr.3-2 & Fr.3-3 & Fr.3-4 & & & & & & \\
\hline $\mathrm{IC}_{50}(\mu \mathrm{g} / \mathrm{ml})$ & $100<$ & 56.6 & 0.589 & $100<$ & & & & & & \\
\hline
\end{tabular}

Table 3. Tyrosinase inhibitory activity of compounds isolated from A. cathartica stem.

\begin{tabular}{ccccccc}
\hline compounds & Kojic acid & Glabridin & Lignan & Kaempferol & Naringenin & Allmandicin \\
$\mathrm{IC}_{50}(\mu \mathrm{M})$ & 43.7 & 2.93 & $100<$ & $100<$ & $100<$ & $100<$ \\
\hline
\end{tabular}

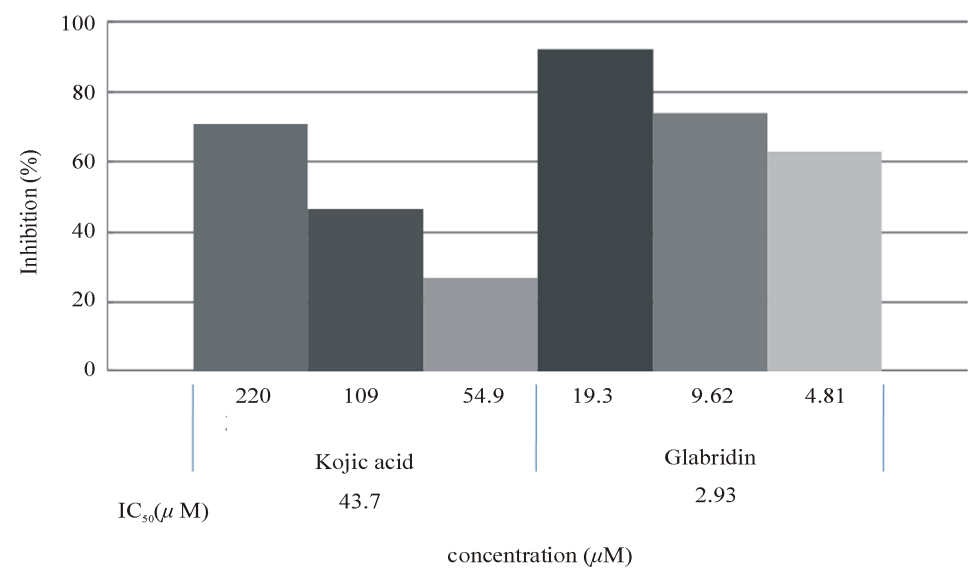

Figure 4. Tyrosinase inhibitory activity of glabridin using tyrosine as the substrate.

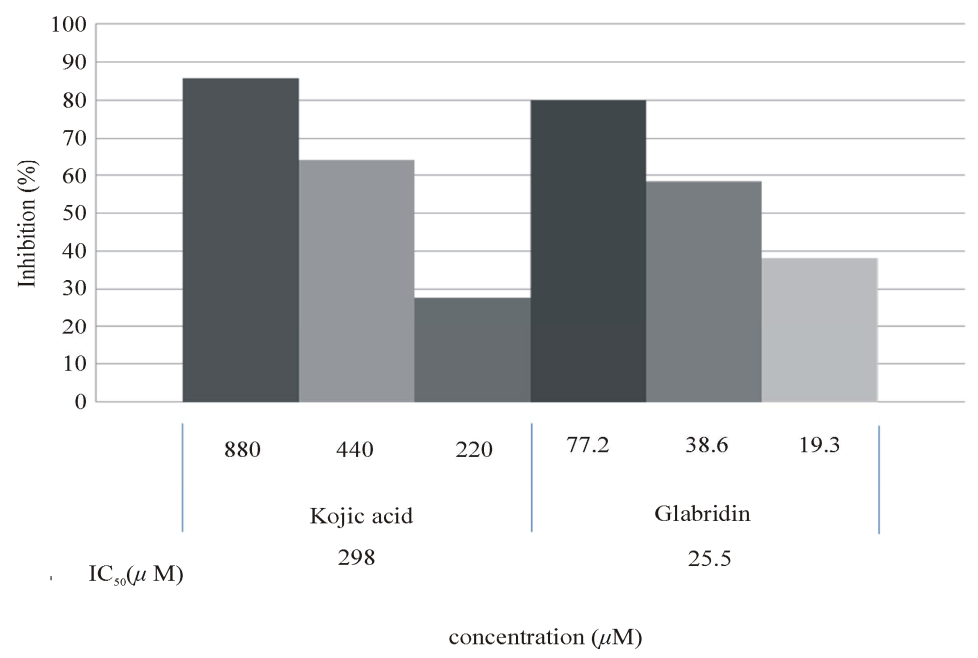

Figure 5. Tyrosinase inhibitory activity of glabridin using DOPA as the substrate.

acid value $298 \mu \mathrm{M}$. Tyrosinase inhibitory activity of glabridin was more than 10 times stronger than that of kojic acid. Thus, glabridin is the center active compound, and possibly has a potent activity for cosmetic as whitening agent.

\section{Conclusions}

In this study, 5 compounds were newly found in $A$. ca- tharitica stem, namely glabridin, new lignin, naringenin, kaempferol and allamandicin. Among all the isolated compounds, glabridin has the most potent tyrosinase inhibitory activity.

\section{REFERENCES}

[1] J. L. C. H. van Valkenburg and N. Bunyapraphatsara, (Eds.), "Plant Resources of South-Ease Asia No 12(2) 
Medicinal and Poisonous Plants 2," Plant Resources of South-East Asia (PROSEA), Bogor, 2002, pp. 49-52.

[2] P. A. Akah and V. N. Offiah, "Gastrointestinal Effects of Allamanda Cathartica Leaf Extracts," International Journal of Pharmacognosy, Vol. 30, No. 3, 1992, pp. 213217. doi:10.3109/13880209209054001

[3] M. J. Balunas and A. D. Kinghorn, "Drug Discovery from Medicinal Plants," Life Sciences, Vol. 78, No. 5, 2005, pp. 431-441. doi:10.1016/j.1fs.2005.09.012

[4] S. Khatib, O. Nerya, R. Musa, M. Shmuel, S. Tamir and J. Vaya, "Chalcones as Potent Tyrosinase Inhibitors: The Importance of a 2,4-Substituted Resorcinol Moiety," Bioorganic \& Medicinal Chemistry, Vol. 13, No. 2, 2005, pp. 433-441. doi:10.1016/j.bmc.2004.10.010

[5] O. Nerya, R. Musa, S. Khatib, S. Tamir and J. Vaya, "Chalcones as Potent Tyrosinase Inhibitors: The Effect of Hydroxyl Positions and Numbers," Phytochemistry, Vol. 65, No. 10, 2004, pp. 1389-1395.

doi:10.1016/j.phytochem.2004.04.016

[6] Z.-P. Zheng, K.-W. Cheng, J. Chao, J. Wu and M. Wang, "Tyrosinase Inhibitors from Paper Mulberry (Broussonetia Papyrifera)," Food Chemistry, Vol. 106, No. 2, 2008, pp. 529-535. doi:10.1016/j.foodchem.2007.06.037

[7] C. Okunji, S. Komarnytsky, G. Fear, A. Poulev, D. M. Ribnicky, P. I. Awachie, Y. Ito and I. Raskin, "Preparative Isolation and Identification of Tyrosinase Inhibitors from the Seeds of Garcinia Kola by High-Speed CounterCurrent Chromatography," Journal of Chromatography A, Vol. 1151, No. 1-2, 2007, pp. 45-50. doi:10.1016/i.chroma.2007.02.085

[8] Azhar-ul-Haq, A. Malik, M. T. H. Khan, Anwar-ul-Haq, S. B. Khan, A. Ahmad and M. I. Choudhary, "Tyrosinase Inhibitory Lignans from the Methanol Extract of the Roots of Vitex Negundo Linn. and Their Structure-Acti- vity Relationship," Phytomedicine, Vol. 13, No. 4, 2006, pp. 255-260. doi:10.1016/j.phymed.2004.09.001

[9] M.-H. Lee, Y.-P. Lin, F.-L. Hsu, G.-R. Zhan and K.-Y. Yen, "Bioactive Constituents of Spatholobus Suberectus in Regulating Tyrosinase-Related Proteins and mRNA in HEMn Cells," Phytochemistry, Vol. 67, No. 12, 2006, pp. 1262-1270. doi:10.1016/j.phytochem.2006.05.008

[10] I. Batubara, L. K. Darusman, T. Mitsunaga, M. Rahminiwati and E. Djauhari, "Potency of Indonesian Medicinal Plants as Tyrosinase Inhibitor and Antioxidant Agent," Journal Biological Sciences, Vol. 10, No. 2, 2010, pp. 138-144. doi:10.3923/jbs.2010.138.144

[11] S. M. Kupchan, A. L. Dessertme, B. T. Blaylock and R. F. Bryan, "Isolation and Structural Elucidation of Allamandin, and Antileukemic Iridoid Lactone from Allamanda Cathartica," The Journal of Organic Chemistry, Vol. 39, No. 17, 1974, pp. 2477-2482. doi:10.1021/jo00931a001

[12] J. J. W. Coppen and A. L. Cobb, "The Occurrence of Iridoids in Plumeria and Allamanda," Phytochemistry, Vol. 22, No. 1, 1983, pp. 125-128. doi:10.1016/S0031-9422(00)80071-0

[13] J. J. W. Coppen, "Iridoids with Algicidal Properties from Allamanda Cathartica," Phytochemistry, Vol. 22, No. 1, 1983, pp. 179-182. doi:10.1016/S0031-9422(00)80083-7

[14] R. Singh, B. Singh, S. Singh, N. Kumar, S. Kumar and S. Arora, "Anti-Free Radical Activities of Kaempferol Isolated from Acacia nilotica (L.) Willd. Ex. Del.," Toxicology in Vitro, Vol. 22, No. 8, 2008, pp. 1965-1970. doi:10.1016/j.tiv.2008.08.007

[15] A.-R. S. Ibrahim, "Sulfation of Naringenin by Cunninghamella Elegans," Phytochemistry, Vol. 53, No. 2, 2000, pp. 209-212. doi:10.1016/S0031-9422(99)00487-2 